\title{
Prince Aleksandr Nevsky:
}

Yaroalavl projection of the historical memory

\section{M. Marasanova ${ }^{1}$}

${ }^{1}$ P. G. Demidov Yaroslavl State University, 14 Sovetskaya str., Yaroslavl 150003, Russian Federation

DOI: $10.18255 / 1996-5648-2021-4-476-487$

Research article Full text in Russian

$2021-800$ th anniversary of prince Aleksandr Nevsky. This date is especially important for the people of the Yaroslavl region, the prince was born in Pereslavl Zalessky. The research of his biography allows to understand the historical conditions of the development of the Yaroslavl principality and adjacent territories after Mongol conquest. The teaching of the national and local history and all disciplines at university is based on the historical and historiographic facts of his life. The Yaroslavl projection of the prince's veneration can be traced back to 17 churches and chapels.

Keywords: Aleksandr Nevsky; Pereslavl Zalessky; Novgorod; diplomacy; faith; historical memory; mongols

\section{INFORMATION ABOUT AUTHORS}

\author{
Marasanova, Victoria M. | E-mail: vmm@uniyar.ac.ru \\ Doc. Sc. (History), Professor
}




\title{
Князь Александр Невский: Ярославская проекция исторической памяти
}

\author{
B. M. Марасанова ${ }^{1}$
}

${ }^{1}$ Ярославский государственный университет им. П. Г. Демидова, ул. Советская, 14 , Ярославль, 150003, Российская Федерация

DOI: 10.18255/1996-5648-2021-4-476-487

Удк 94(47)+908

Научная статья

Полный текст на русском языке

В 2021 году отмечается 800-летие со дня рождения Александра Невского. Юбилейная дата особенно важна для ярославцев, поскольку князь родился в Переславле-Залесском. Изучение его биографии позволяет понять исторические условия развития Ярославского княжества и сопредельных территорий после монгольского нашествия. На исторических и историографических фрактах его биографии строится преподавание отечественной и региональной истории, общих и специальных дисциплин всех уровней высшего образования. Ярославскую проекцию почитания князя позволяют проследить 17 храмов и часовен в его честь.

ключевые слова: Александр Невский; Переславль-Залесский; Новгород; дипломатия; вера; историческая память; монголы

\section{ИНФОРМАЦИЯ ОБ АВТОРАХ}

\author{
Марасанова, Виктория $\mid$ E-mail:vmm@uniyar.ac.ru \\ Михайловна Доктор исторических наук, профессор
}

В 2021 году отмечается 800-летие со дня рождения Александра Невского. 24 июня 2014 года Президент Российской Федерации В. В. Путин подписал Указ «О праздновании 800-летия со дня рождения Александра Невского», как подчеркивается, «в целях сохранения военно-исторического и культурного наследия, укрепления единства российского народа» [1].

Юбилейная дата особенно важна для ярославцев, для тех, кто родился и живет на этой исторической территории. Северо-Востоком управляли Юрий Долгорукий и его потомки - Андрей Боголюбский, Всеволод Большое Гнездо, Юрий Всеволодович. От них вели родословие ростовские, ярославские, переславские, угличские, мологские и другие удельные князья. В 1152 году князем Юрием Долгоруким был основан город Переславль-Залесский - место рождения великого воина и дипломата, святого благоверного князя Александра Невского (1221-1263). Изучение биографии князя позволяет понять исторические условия развития Ярославского княжества 
Марасанова В. М.

и сопредельных территорий после монгольского нашествия. На исторических и историографических фрактах его биографии строится преподавание отечественной и региональной истории, общих и специальных дисциплин всех уровней высшего образования. В связи с этим важно сорормулировать и аргументировать позицию по дискуссионным проблемам биографии князя и в целом истории его времени.

Историографическая традиция изучения жизни и трудов князя Александра Невского насчитывает несколько веков. О нем пишут авторы церковные и светские, гражданские и военные, российские и зарубежные. Пожалуй, о нем написано больше, чем о других русских князьях. Это закономерно, но требует особой ответственности от тех, кто вновь решил обратиться к истории жизни воина, правителя, христианина. И каждый, кто решил уточнить, написать или переписать биографрюю Александра Ярославича, находит свой путь и свои оценки для представления личности героя. Споры по конкретным вопросам и общим выводам в научном сообществе и на просторах Интернета то затухают, то вспыхивают с новой силой. Значит, это история не только о прошлом, но и о сегодняшнем дне.

Исследователи отмечают полководческие и дипломатические таланты князя, особо выделяют его успехи по отражению агрессии на северо-западных границах русских земель. Вслед за историками XVIII (В. Н. Татищев [2]) и XIX веков (Н. М. Карамзин [3], С. М. Соловьев [4], В. О. Ключевский [5] и др.) эту традицию продолжили работы А. Н. Сахарова [6], В. Т. Пашуто [7] и др. В дореволюционном ярославском родиноведении Александр Невский не считался местным князем, поскольку Переславский уезд относился к Владимирской губернии. Следовательно, местная традиция изучения его деятельности складывалась только в ХХ столетии.

Большинство историков обоснованно считают, что во взаимоотношениях с монголами Александр Невский действовал в соответствии с обстоятельствами, учитывая превосходящие силы противника, однако Л. С. Гумилев доказывал наличие тесного союза между русскими князьями и Золотой Ордой и шел еще дальше, вообще отрицая наличие ига на Руси [8].

Академик В. Л. Янин встал на позиции средневековых новгородцев, считая, что по отношению к Новгороду князь Александр проявил излишнюю жестокость в вопросе о сборе ордынской дани [9]. Для уничтоженных и разграбленных в 1237-1238 годах городов Северо-Востока это явно недостаточно убедительная аргументация.

Из средневековых источников перекочевали в исторический труд Джона Феннела сомнения в значимости битв Александра Невского на северо-западных рубежах Руси [10]. Возможно, более широкое знакомство автора с русскими летописями, церковными источниками и археологическими данными поколебало бы его точку зрения.

Основные сведения по истории Северо-Восточной Руси в XIII столетии дает Лаврентьевская летопись 1377 года, сохранившая фррагменты 
Князь Александр Невский: Ярославская проекция исторической памяти...

владимирского и ростовского летописания [11]. При изучении событий XIII столетия и фактов из жизни князя Александра Ярославича важны также летописание Новгорода [12] и Пскова [13]. Для удобства можно обратиться к статье Я. С. Лурье, где собраны летописные свидетельства о князе [15].

Церковная традиция сохранила тексты житий Александра Невского, которые составлялись во Владимире, Новгороде, Пскове. Один из древнейших списков жития князя, датируемый концом XV века, подготовлен к публикации В. И. Охотниковой. Она отмечает, что «Повесть о житии Александра Невского» не имеет устойчивого названия и именуется «житием», «словом» или «повестью о житии»; сохранилось 13 редакций текста XV-XVII веков. Произведение представляет собой княжескую биографию, соединяющую черты жития и воинской повести. Составление первоначального текста относят к 1280-м годам и связывают с именами сына князя Дмитрия Александровича и митрополита Кирилла. Автор жития был современником князя. При этом в житии нет дат, автор почти не называет имен, не всегда точен в изложении событий. Он описывает Невскую битву, Ледовое побоище, отношения князя Александра с Золотой Ордой и его смерть [15].

Князь Александр Невский родился в Переславле-Залесском 13 (либо 30) мая 1221 года по старому стилю. В источниках и литературе приводятся также даты 1219 или 1220 год; в литературе обоснование даты 1221 год см. у В. А. Кучкина [16]. Князя назвали в честь святого Александра, подвиги которого церковь вспоминает 9 июня. Спасо-Преображенский собор - древнейший на территории Ярославской области храм, место, где крестили князя. В XIII-XIV веках собор стал усыпальницей переславских князей, здесь были погребены сын и внук Александра Невского - князья Дмитрий Александрович (1250-1294) и Иван Дмитриевич (1268-1305).

Жизнь и государственная деятельность Александра Невского пришлись на один из самых трудных периодов в российской истории. В XIII веке по Северо-Восточной Руси прошёл поход хана Батыя. Переславль-Залесский в середине февраля 1238 года пал после пятидневной осады. Ростов и Углич сдались без боя. О захвате монголами Ярославля летописи не сообщали. Однако археологические раскопки начала XXI века в Ярославле на месте строительства Успенского собора позволили обнаружить девять массовых захоронений с останками более пятисот человек, в основном женщин и детей, со следами насильственной смерти в культурном слое XIII столетия.

В Ростове, Ярославле и Угличе с 1218 года княжили племянники князя Юрия, дети его старшего брата Константина Мудрого - Василько, Всеволод и Владимир. Они пришли с дружинами на реку Сить, где к ним присоединилась дружина юрьев-польского князя Святослава Всеволодовича, брата владимирского князя. Княжеские дружины были рассредоточены на значительной территории, ныне это Ярославская и Тверская области РФ. 4 марта 1238 года в битве на реке Сить погибли великий владимирский князь Юрий 
Марасанова В. М.

и ярославский князь Всеволод. Ростовский князь Василько был взят в плен и убит за отказ сотрудничать с монголами. В живых остались угличский князь Владимир и юрьев-польский князь Святослав Всеволодович.

После разгрома русских сил монголы заняли Тверь и вступили в Новгородскую землю. После двухнедельной осады Торжка Батый повернул на юг, и на этом пути более семи недель длилась осада Козельска. Монголы потратили три месяца на всю Северо-Восточную Русь и почти два месяца на один город. Удлинение сроков осады городов можно связать с последствиями Ситской битвы, ослабившей неприятеля. Несмотря на тяжелейшее поражение, битва на реке Сить должна быть отмечена как попытка пяти князей совместно выступить против общего врага под руководством великого владимирского князя. Только спустя полтора века русские силы смогли одержать победу над монголами на Куликовском поле.

Часть Руси (Новгородская земля, Полоцкое, Турово-Пинское, Смоленское княжества) избежала монгольского вторжения. В конце 1240 года монголы взяли Киев, и этим моментом датируется установление монгольского ига. Однако уже более века, с 1132 года, единого Древнерусского государства со столицей в Киеве не существовало. Великое Владимирское княжество было сильным независимым государством. Для него новый этап истории начался не в 1240 , а в 1238 году.

После гибели Юрия Всеволодовича старшим из сыновей Всеволода Большое Гнездо стал князь Ярослав Всеволодович. В 1243 году князь Ярослав получил ярлык о признании «старейшим князем Руси». Золотая Орда как государство было оформлено в 1242 году. Но русские земли сохранили свои фрормы правления, оставаясь монархиями-княжествами или имея республиканскую фрорму правления в случае Новгорода и Пскова. Не менее важным было сохранение православной веры и церковного устройства.

Князь Ярослав не ладил с непокорными новгородцами и постоянно пребывал в Переславле-Залесском, но в Новгороде оставил сыновей Федора и Александра. Согласно Новгородской первой летописи, это произошло в 1228 году. Летом 1233 года Федор неожиданно скончался. Теперь Александр был старшим из сыновей Ярослава и в 1236 году, в 15-летнем возрасте, был офрициально посажен на новгородский престол. Новгородским князем Александр оставался с перерывами до 1259 года.

В то время, когда отец, князь Ярослав, пытался защитить русские земли от новых ударов монголов, сын отражал угрозу, нависшую над русскими землями с северо-запада. Дробление и ослабление военной силы Руси не осталось незамеченным ее соседями. Оставив в стороне известную фактологию, напомним, что 15 июля 1240 года Александром был разбит шведский отряд на Неве. В Новгородской первой летописи имя «Невский» фикксируется по внелетописным дополнениям XV века. «Невскими» источники XVII века называли сыновей Александра - Андрея и Даниила, и можно со- 
Князь Александр Невский: Ярославская проекция исторической памяти...

гласиться с тем, что в этом имени фиксировался географический момент, т. е. указывалось на владения князей на реке Неве. Противник Александра в Невской битве Биргер в 1248 году стал ярлом Швеции, а через два года регентом при сыне-короле Вальдемаре. Ярл Биргер известен как основатель Стокгольма. Опытный воин и политик понял, что натиск на новгородские и псковские земли будет решительно пресекаться. При этом в шведских источниках нет упоминания о Невской битве.

Новгородское боярство боялось укрепления влияния князя, поэтому Александр был вынужден уехать во Владимир (либо в Переславль). В это время псковский посадник Твердило Иванкович при поддержке немцев и чуди начал войну с Новгородом. После просьбы новгородского архиепископа в 1241 году Александр вернулся в Новгород, собрал ополчение из новгородцев и ладожан, присоединил к нему корелу и ижору и изгнал немцев из новгородской округи. Когда отряд Александра подошел к городу, псковичи сами сместили посадника и открыли ворота.

Для защиты границ от набегов отряд Александра выдвинулся во владения Ливонского ордена на земли эстов и 5 апреля 1242 года одержал победу на льду Чудского озера [17]. По сведениям новгородских источников, в плен попало 50 рыцарей, а погибло 400 человек. В немецких хрониках сообщалось о гибели 25 воинов ордена. После Ледового побоища натиск рыцарей на Восток был надолго остановлен. Мир был установлен на условиях новгородцев, а Ливонский орден отказывался от всех притязаний на русские земли.

Летом 1242 года Александр нанес поражение литовским отрядам, нападавшим на северо-западные русские земли. В 1245 году он отбил у литовцев город Торопец, уничтожил литовский отряд у озера Ж⿱изца (Жћижицкого озера) и разгромил литовское ополчение под Усвятом. В начале 1250-х годов князь Александр смог остановить набеги норвежцев на новгородские земли и заключил мирный договор с королем-конунгом Норвегии Хаконом IV Старым. Пограничные споры и сбор дани с местных племен были на время урегулированы. Неспокойно было на северо-западных границах и в следующем десятилетии. Когда большая часть княжеств пережила монгольское нашествие, а города лежали в руинах, действия князя Александра показали, что силы на борьбу еще остались.

В дальнейшем Александру Невскому пригодились не столько военные, сколько дипломатические таланты, поскольку для борьбы с монголами русские земли не располагали достаточными силами. Он помнил результаты нашествия Батыя и гибель своего дяди - великого владимирского князя Юрия - с двоюродными братьями Всеволодом и Василько Константиновичами на реке Сить, смерти бояр и горожан. Возможно, историкам тоже стоило чаще вспоминать эти страшные страницы русской истории, прежде чем ставить князю Александру в упрек сотрудничество с монголами. 
Марасанова В. М.

Во второй раз князь Ярослав Всеволодович был вызван ханом Гуюком в Каракорум в 1246 году и там, по общепринятой версии, отравлен регентшей престола Туракиной, вдовой хана Угедея и матерью хана Гуюка. Так что даже богатые дары и смирение не всегда спасали жизнь, и каждая поездка в Сарай или Каракорум могла быть последней.

Александр присутствовал на похоронах отца во Владимире, прибыв туда из Новгорода с дружиной. Следуя летописным свидетельствам, «и бысть грозен приезд его», что явно не соответствовало образу подчинившегося монголам князя. Новым великим владимирским князем был избран следующий по старшинству из сыновей Всеволода Большое Гнездо - Святослав (участник Ситской битвы). Летопись не сообщает о том, по каким причинам Святослав не отправился в Орду за ярлыком, но известно, что через год владимирский престол был отнят у него младшим братом Михаилом Хоробритом. В 1248 году Михаил погиб в военном конфликте с Литвой, и великий владимирский престол ждал нового князя.

Еще в 1247 году в Каракорум были вызваны сыновья Ярослава - Александр и Андрей. Путь в Каракорум шел через Золотую Орду, и, согласно житию Александра Невского, он отказался проходить унизительный обряд перед встречей с правителем западного улуса наместником монгольского хана Батыем, но тот не казнил князя [18]. Но и, помимо этого, сама поездка к ордынскому правителю и далее к главному хану монголов была делом непростым и занимала 3-4 месяца -7 тыс. км в одну сторону. Побывав в Каракоруме, князь Александр увидел многие страны и народы. В монгольской столице решались важнейшие вопросы, утверждалось престолонаследие монголов и покоренных народов, изготавливалось оружие монголов, велись переговоры и торговля. Александр оценил мощь Золотой Орды и собственно Монгольской империи, лучше понял врага, с которым пока невозможно было бороться, но надо было сосуществовать.

Братья смогли вернуться на Русь только в 1249 году: по летописи, в конце года князь Александр присутствовал на похоронах князя Владимира Константиновича во Владимире. Однако хан отдал Великое Владимирское княжество с Переславлем-Залесским младшему брату Андрею (несмотря на то, что еще был жив его дядя, ранее свергнутый князь Святослав), а старшему Александру отдал Киев. Разграбленный Киев уже давно не был главным городом для распавшейся на отдельные княжества и земли Древней Руси, и Александр разумно попытался укрепиться на новгородском престоле. Нет свидетельств о поездках Александра в Киев. Но по летописям известно, что в 1251 году он тяжело болел и не покидал Новгород.

Князь Андрей в 1250 году женился на дочери князя Даниила Галицкого, что создавало предпосылки для широкой антиордынской коалиции. В 1252 году в Каракоруме жена хана Гуюка - Огуль-Гамиш - была свергнута новым монгольским каганом Менке (Менгу, Мунке). Решив сместить с владимирского престола Андрея Ярославича, Батый решил передать яр- 
Князь Александр Невский: Ярославская проекция исторической памяти...

лык Александру. Для этого князь Александр был срочно вызван в столицу Золотой Орды - город Сарай. Но Андрей, поддержанный братом Ярославом, на тот момент тверским князем, и Даниилом Романовичем Галицким, отказался подчиниться решению Батыя. Для наказания непокорных князей Батый отправил на Русь «Неврюеву рать», и князья-братья Андрей и Ярослав бежали соответственно в Швецию и Псков.

Александр по приказу хана выехал в Орду до похода Неврюя, и Батый признал его в 1252 году владимирским князем. Рассуждения Льва Гумилева о том, что в Орде князь Александр прошел обряд братания с сыном Батыя ханом Сартаком не подтверждены источниками и остаются личным предположением автора. $\mathrm{K}$ слову, старый конфликт между братьями Александром и Андреем был разрешен без усобиц, дипломатическим путем. В 1257 году оба брата отправились в Орду, где Андрей получил полное прощение.

Новый золотоордынский хан Берке с 1255 года ввел на Руси систему обложения данью. Такая административно-фрискальная система являлась выражением ига. Для уточнения размеров повинностей с участием присланных центральным монгольским правительством «численников» проводилось «число» - перепись населения. Счет велся не по душам, а по семейных хозяйствам - дворам. В 1257-1259 годах проводилось «число» в суздальских, рязанских и муромских землях.

Перепись спровоцировала несколько восстаний против монголов. В Ярославле в июле 1257 году в легендарном сражении на Туговой горе погибли князь Константин Всеволодович и многие ярославцы.

Монгольские войска во время похода 1237-1238 годов не дошли до Великого Новгорода, и новгородцы считали себя непокоренными. Все отношения с Ордой велись через владимирского князя, и посланники ханов в городе появлялись довольно редко. Силу монгольского войска новгородцы не видели и потому не помнили. В результате в 1257 году Новгород восстал против монгольской дани. Новгородцы в вопросе об уплате дани не подчинились даже Александру Невскому, еще и его сын Василий пошел против отца. Опасаясь отцовского гнева, Василий уехал в Псков, а обстановка в Новгороде все более накалялась. Посадник Михаил, поддерживавший Александра, был казнен по решению веча. Когда к зиме приехал князь Александр с монгольским посольством, князя Василия Александровича отыскали и под стражей увезли во Владимир, а непокорным боярам отрезали носы и ослепили.

Зимой 1259 года, узнав о возможном нападении монголов и владимирцев, новгородцы согласились провести перепись. Однако опять начались волнения, вече выступило против уплаты дани. После этого князь Александр и монгольские послы уехали, что было равнозначно разрыву мира. С большим трудом бояре - сторонники Александра - убедили вече платить 
дань, чтобы спастись от полного разорения. Новым новгородским наместником с 1259 года стал князь Дмитрий Александрович.

Новые антимонгольские восстания в Ярославле, Ростове и Суздале произошли в 1262 году. Горожане выступили против сборщиков дани, присланных императором Хубилаем, а не золотоордынским ханом Берке. Ярославцы изгнали ханских переписчиков и убили помогавшего им местного жителя монаха-отступника Изосима (Зосиму), а его труп бросили на съедение собакам. В том же году произошли восстания в Ростове и Суздале [19].

Чтобы избавить русские земли от неизбежного карательного похода, князь Александр отправился в столицу Золотой Орды на Волге - Сарай. Он убедил монголов отказаться от кровавой мести, и это стало его последним вкладом в сохранение городов и населения Северо-Восточной Руси. Основной целью поездки было убедить Золотую Орду не требовать русских отрядов для войны с Ираном, и Александру удалось это сделать.

Александр Невский умер по дороге домой в Городце на Волге 14 ноября 1263 года. В общей сложности князь провёл в Золотой Орде больше четырёх лет. Перед смертью Александр Ярославич принял схиму и иноческое имя Алексия. Чин погребения был совершён митрополитом Кириллом во Владимире 23 ноября. Источники донесли до нас слова митрополита о смерти князя: «Зашло солнце Русской земли».

Князь не мог свергнуть иго, но делал всё возможное для ослабления его тягот, например добился ограничения принудительных воинских наборов в русских землях для участия в монгольских походах. С 1269 года дань собирали не баскаки - ордынские чиновники, а сами русские князья.

Все действия князя Александра Невского не только спасали русские земли от набегов, но и защищали православную веру. Монголы исповедовали ислам, а рыцарские ордена под покровительством Рима стремились распространить католичество на Восток. Князь Александр в 1239 году вступил в брак с дочерью полоцкого князя Брячислава - Александрой и этим тоже помог в укреплении православия на пограничных с католическими государствами землях. Венчание княжеской четы происходило в Торопце, а брачные пиры в Торжке и Новгороде. У княжеской четы родились четыре сына - Василий, Дмитрий, Андрей и Даниил - и дочь Евдокия. Супруга князя Александра и их дочь Евдокия погребены в Успенском соборе Успенского Княгинина монастыря во Владимире.

Князь Александр восстанавливал православные храмы и многое сделал для выкупа пленных. В 1250 году князь пригласил митрополита Кирилла из Киева во Владимир. Благодаря усилиям Александра Невского и митрополита Кирилла, была учреждена Сарайская епархия. Во главе этой обширной епархии - между Волгой, Днепром и Доном - встал епископ Митрофан. Так была обеспечена духовная поддержка русских пленных в Орде. 
Князь Александр Невский: Ярославская проекция исторической памяти...

Уже в $1280-$ х годах во Владимире начинается почитание Александра Невского как святого. Князь был канонизирован Русской православной церковью в правление Ивана Грозного на Московском церковном соборе 1547 года, и как общегосударственный день его прославления было установлено 23 ноября. Известно, что в начале XVII века в Москве уже действовал храм в честь Александра Невского.

Особую страницу составляет почитание Александра Невского императорским домом Романовых. Петр I основал в Санкт-Петербурге монастырь в честь князя Александра и повелел перевезти туда останки князя из Владимира, где они почивали в Рождественском монастыре. Мощи встречали в столице 30 августа 1724 года. В честь побед русского оружия Петр I постановил отмечать память Александра Невского 30 августа - в день заключения Ништадтского мира со Швецией. В наши дни, помимо 30 августа (по новому стилю 12 сентября) и 23 ноября (6 декабря), память святого благоверного князя празднуется 23 мая (5 июня) в соборе Ростово-Ярославских святых и 22 сентября - в соборе Тульских святых.

В 1725 году Екатерина I учредила орден Александра Невского. Дочь Петра I и Екатерины I императрица Елизавета Петровна повелела устроить для мощей святого благоверного князя серебряную раку из 1,5 тонн серебра. При Екатерине II в праздничный день 30 августа 1794 года раку с мощами перенесли во вновь построенный Троицкий собор. И, наконец, в 1797 году при Павле I Александро-Невский монастырь стал Александро-Невской лаврой, т. е. вошел в число главнейших монастырей России. После антирелигиозных гонений советского времени в 1989 году мощи князя были возвращены в Александро-Невскую лавру из Музея религии и атеизма в Казанском соборе (ныне вновь действующий храм). Серебряная рака находится в экспозиции Государственного Эрмитажа.

Любовь к Отечеству и готовность встать на его защиту - вневременные абсолютные ценности. В советские годы, накануне войны, в 1938 году Сергей Эйзенштейн снял фильм «Александр Невский», вошедший в «золотой фонд» отечественного кинематографа. Во время Великой Отечественной войны в 1942 году был учрежден орден Александра Невского, которым награждались командиры от взводов до дивизий включительно, проявившие личную отвагу и обеспечившие успешные действия своих частей.

Ярославские авторы Вениамин Попов и Алексей Хаиров составили перечень земляков, получивших орден Александра Невского в Российской империи и СССР [20]. Память великого земляка увековечена по всей стране в названиях улиц. В Переславле в 1958 году рядом со Спасо-Преображенским собором на Красной площади установлен памятник Александру Невскому работы скульптора Сергея Орлова.

По данным сайта «Храмы России» (http://temples.ru/) на территории Российской Федерации известно 700 храмов, посвященных Александру Невскому; 407 из них являются действующими. На территории Ярославской 
области зафиксировано 17 храмов и часовен с посвящением святому благоверному князю, что является свидетельством внимания и любви к нему на ярославской земле. Из 17 объектов действующими либо строящимися являются 4 храма и 5 часовен:

- церковь Александра Невского в Переславле (ул. Советская, 12), построена в 1740-е годы;

- церковь Александра Невского в с. Макарово Рыбинского района, даты строительства 1913-1919 гг.;

- церковь Александра Невского при кадетском корпусе в Новоалексеевке, Переславский район, построена в 2000-е гг.;

- церковь Александра Невского при Переславской православной гимназии, г. Переславль (ул. Менделеева, 10), освящена в 2002 г.;

- часовня Александра Невского (часовня Успенского собора), г. Ярославль, ул. Андропова, 8, даты строительства 1889-1892 гг.;

- часовня Александра Невского в с. Заозерье, Угличский район, 1894 г.;

- часовня Александра Невского в г. Любиме, даты строительства 1884-1888 гг.;

- часовня Александра Невского в мемориале защитникам Отечества во все времена, г. Углич, Успенская площадь, строилась в 2003-2004 гг.;

- часовня Александра Невского в Николо-Сольбинском монастыре, Переславский район, строится.

К утраченным памятникам относятся 5 церквей: церковь Александра Невского (1875) в с. Воскресенском Некоузского района, при Демидовском юридическом лицее (1825-1827), в д. Хопылево (1908-1910) Рыбинского района, при б. тюремном замке в г. Угличе (1860) и при Ярославской губернской земской больнице (1805-1807), а также 3 часовни: в Угличе («в воспоминание ополчения 1855 года»), в д. Горки Некрасовского района и с. Ильинском Угличского района.

Князь Александр Невский всегда ставил заботу о Руси и русском народе выше удельных и личных интересов. Будучи князем и новгородским, и великим киевским (формально), и великим владимирским Александр Невский всегда проводил общерусскую политику, мыслил стратегически, был одновременно воином и дипломатом. В сложнейших условиях Александр Невский обезопасил западные границы Руси и выстроил умелую политику по отношению к монгольским завоевателям. Его действия против шведов, немецких рыцарей и литовцев на северо-западных границах доказали, что даже ослабленная монголами Русь в состоянии отстоять свою самостоятельность и веру. Младший сын Александра Невского - Даниил - стал первым московским удельным князем и в числе его потомков Иван Калита, Дмитрий Донской, Иван Грозный. Через полвека после смерти князя, в 1314 году, около Ростова родился боярский сын Варфоломей, будущий преподобный Сергий Радонежский. Вслед за святым благоверным кня- 
Князь Александр Невский: Ярославская проекция исторической памяти...

зем Александром Невским пришли новые поколения героев и духовных подвижников.

Ссылки

1.Указ Президента РФ «О праздновании 800-летия со дня рождения Александра Невского» от 24.06.2014. URL: www.kremlin.ru/acts/news/46050 (дата обращения: 17.02.2021).

2. Татищев В. Н. История Российская: в 7 т. Т. 5 / под ред. С. Н. Валка и М. Н. Тихомирова. М.; Л.: Изд-во Акад. наук СССР., Ленингр. отд-е, 1965. 343 с.

3. Карамзин Н. М. История государства Российского. М.: Эксмо, 2009. 1020 с.

4. Соловьев С. М. История России с древнейших времен до конца XVIII века // Соловьев С. М. Сочинения: в 18 кн. Кн. 1: Т. 1-2. М.: Голос, 1993.768 с.

5. Ключевский В. О. Курс русской истории. М.: Академ. проект, 2015. Лекции I-XXIX : от древности до эпохи Ивана Грозного. 485 с.

6. Александр Невский / авт. А. Н. Сахаров. М.: АСТ; Астрель, 2008. 127 с.

7. Пашуто В. Т. Александр Невский. М.: Мол. гвардия, 1974. 160 с. («Жћизнь замечательных людей»).

8. Гумилев Л. Н. Древняя Русь и Великая степь. М.: Айрис-Пресс, 2005. 763 с.

9. Янин В. Л. «Александр Невский был грешником» - лекция на телеканале «Культура» в рамках проекта ACADEMIA. URL: http:/www.aif.ru/academy/ article/34285 (дата обращения: 14.03.2021).

10. Феннел Дж. Кризис средневековой Руси: 1200-1304 / пер. с англ. В. В. Голубчикова; вступ. ст. и общая ред. А. Л. Хорошкевич, А. И. Плигузова. М.: Прогресс, 1989. $291 \mathrm{c}$.

11. Полное собрание русских летописей. Т. 1: Лаврентьевская летопись. М.: ЯРК, 1997. $496 \mathrm{c}$.

12. Полное собрание русских летописей. Т. 3: Новгородская первая летопись старшего и младшего изводов. М.: ЯРК, 2000. 720 с.

13. Псковские летописи. М.: ЯРК, 2003. Т. 5, вып. 1. 256 с.

14. Лурье Я. С. К изучению летописной традиции об Александре Невском // Труды отдела древнерусской литературы (ТОДРЛ). СПб., 1997. Т. 1, ч. 1. С. 387-399.

15. Житие Александра Невского / подгот. текста, пер. и коммент. В. И. Охотниковой // Памятники литературы Древней Руси. М.: Худ. лит., 1981. Вып. 3 : XIII век. C. $426-439$.

16. Кучкин В. А. О дате рождения Александра Невского // Вопросы истории. 1986. № 2. С. 174-176.

17. Данилевский И. Н. Ледовое побоище: смена образа // Отечественные записки. 2004. № 5. С. 28-40.

18. Егоров В. Л. Александр Невский и Чингизиды (политические взаимоотношения России с Золотой Ордой в конце XIII в.) // Отечественная история. 1997. № 2. C. $48-58$.

19. Страницы военной истории Ярославии / под ред. В. М. Марасановой. Ярославль: Индиго, 2013. 208 с.

20. Попов В. Г., Хаиров А. Р. Ярославцы - кавалеры ордена Александра Невского. Рыбинск: Рыбин. подворье, 2003. 348 с. 